Although fasting insulin is used as a surrogate measure of insulin resistance, it has a stronger correlation with insulin clearance, which is highly heritable $(19,20)$. Future human genetic studies will be important for determining whether genetic variation in SLC30A8 contributes to T2D entirely through its effect on insulin clearance and how much of the heritability of insulin clearance is due to $S L C 30 A 8$.

These studies illustrate how in-depth phenotyping, which requires model organisms, can take clues from human genetics and provide mechanistic explanations for relationships between genetic variation and human disease. Results from these studies can now be used to study subphenotypes associated with diabetes susceptibility. In this case, it may motivate study of the relationship among inorganic physiology (such as the $\mathrm{Zn}^{2+}$ fluxes described here), genetic variation at the SLC30A8 locus, and insulin clearance. Most importantly, these deeper phenotypes should be present in nondiabetics, and thus can be studied independently of the disease.

Address correspondence to: Thomas V. O'Halloran, Northwestern University, 2145 Sheridan Road, Evanston, Illinois 60208-3113, USA. Phone: 847.491.5060; Fax: 847.467.1566; E-mail: t-ohalloran@ northwestern.edu. Or to: Alan D. Attie, University of Wisconsin-Madison, 433 Babcock Drive, Madison, Wisconsin 53706, USA. Phone: 608.262.1372; Fax: 608.262.4705; E-mail: adattie@wisc.edu.

1. Kim AM, et al. Zinc sparks are triggered by fertilization and facilitate cell cycle resumption in mammalian eggs. ACS Chem Biol. 2011;6(7):716-723.

2. Outten CE, O'Halloran TV. Femtomolar sensitivity of metalloregulatory proteins controlling zinc homeostasis. Science. 2001;292(5526):2488-2492.

3. Tamaki $\mathrm{M}$, et al. The diabetes-susceptible gene SLC30A8/ZnT8 regulates hepatic insulin clearance. J Clin Invest. 2013;123(10):4513-4524.

4. Chimienti F, Devergnas S, Favier A, Seve M. Identification and cloning of a $\beta$-cell-specific zinc transporter, ZnT-8, localized into insulin secretory granules. Diabetes. 2004;53(9):2330-2337.

5 . Wenzlau JM, et al. The cation efflux transporter ZnT8 (Slc30A8) is a major autoantigen in human type 1 diabetes. Proc Natl Acad Sci U S A. 2007;104(43):17040-17045.

6. Sladek R, et al. A genome-wide association study identifies novel risk loci for type 2 diabetes. Nature. 2007;445(7130):881-885

7. Qian WJ, Gee KR, Kennedy RT. Imaging of $\mathrm{Zn}^{2+}$ release from pancreatic $\beta$-cells at the level of single exocytotic events. Anal Chem. 2003;75(14):3468-3475.

8. Cheng-Xue R, et al. Tolbutamide controls glucagon release from mouse islets differently than glucose: involvement of K(ATP) channels from both $\alpha$-cells and $\delta$-cells. Diabetes. 2013;62(5):1612-1622.

9. Nicolson TJ, et al. Insulin storage and glucose homeostasis in mice null for the granule zinc transporter ZnT8 and studies of the type 2 diabetes-associated variants. Diabetes. 2009;58(9):2070-2083

10. Pound LD, et al. The physiological effects of delet- ing the mouse SLC30A8 gene encoding zinc transporter- 8 are influenced by gender and genetic background. PLoS One. 2012;7(7):e40972.

11. Pound LD, et al. Deletion of the mouse Slc30a8 gene encoding zinc transporter- 8 results in impaired insulin secretion. Biochem J. 2009;421(3):371-376.

12. Lemaire $\mathrm{K}$, et al. Insulin crystallization depends on zinc transporter $\mathrm{ZnT} 8$ expression, but is not required for normal glucose homeostasis in mice. Proc Natl Acad Sci U S A. 2009;106(35):14872-14877.

13. Wijesekara N, et al. Beta cell-specific Znt8 deletion in mice causes marked defects in insulin processing, crystallisation and secretion. Diabetologia. 2010;53(8):1656-1668.

14. Hardy $A B$, et al. Effects of high-fat diet feeding on Znt8-null mice: differences between $\beta$-cell and global knockout of Znt8. Am J Physiol Endocrinol Metab. 2012;302(9):E1084-E1096.

15. Zhu X, Orci L, Carroll R, Norrbom C, Ravazzola M, Steiner DF. Severe block in processing of proinsulin to insulin accompanied by elevation of des-64,65 proinsulin intermediates in islets of mice lacking prohormone convertase 1/3. Proc Natl Acad SciUS A. 2002;99(16):10299-10304.

16. Menting JG, et al. How insulin engages its primary binding site on the insulin receptor. Nature. 2013;493(7431):241-245.

17. Beintema JJ, Campagne RN. Molecular evolution of rodent insulins. Mol Biol Evol. 1987;4(1):10-18.

18. Bancila $V$, et al. Two SUR1-specific histidine residues mandatory for zinc-induced activation of the rat KATP channel. J Biol Chem. 2005;280(10):8793-8799.

19. Goodarzi MO, et al. Systematic evaluation of validated type 2 diabetes and glycaemic trait loci for association with insulin clearance. Diabetologia. 2013;56(6):1282-1290.

20. Goodarzi MO, Cui J, Chen YD, Hsueh WA, Guo $\mathrm{X}$, Rotter JI. Fasting insulin reflects heterogeneous physiological processes: role of insulin clearance. Am JPhysiol Endocrinol Metab. 2011;301(2):E402-E408.

\title{
Opening lines of communication in the distal nephron
}

\author{
Thomas R. Kleyman, ${ }^{1}$ Lisa M. Satlin, ${ }^{2}$ and Kenneth R. Hallows ${ }^{1}$
}

\begin{abstract}
${ }^{1}$ Renal-Electrolyte Division, Department of Medicine, and Department of Cell Biology, University of Pittsburgh School of Medicine, Pittsburgh, Pennsylvania, USA. ${ }^{2}$ Department of Pediatrics, The Icahn School of Medicine at Mount Sinai, New York, New York, USA.
\end{abstract}

\begin{abstract}
The distal nephron is composed of two main cell types: principal cells and intercalated cells. These cells have distinct morphologic features that allow them to be readily distinguished by light microscopy, as well as distinct suites of proteins that facilitate cell-specific transport properties. In this issue of the JCI, Gueutin and colleagues describe a new mechanism by which $\beta$-intercalated cells, via release of ATP and prostaglandin $\mathrm{E}_{2}\left(\mathrm{PGE}_{2}\right)$, influence the activity of transporters in principal cells.
\end{abstract}

\section{Challenging tradition}

The traditional view of the distal nephron considers principal cells to be primarily

Conflict of interest: Kenneth R. Hallows is the principal investigator of a grant to the University of Pittsburgh from Dialysis Clinics Inc. to study the role of kinases in kidney epithelial transport regulation.

Citation for this article: J Clin Invest. 2013; 123(10):4139-4141. doi:10.1172/JCI71944. responsible for reabsorption of filtered $\mathrm{Na}^{+}$ and for $\mathrm{K}^{+}$secretion into the ultrafiltrate, whereas intercalated cells account for urinary acidification. Sodium reabsorption by principal cells occurs via the $\mathrm{Na}^{+} / \mathrm{Cl}^{-}$ cotransporter (NCC) in the early distal nephron and the epithelial $\mathrm{Na}^{+}$channel $(\mathrm{ENaC})$ in later nephron segments. Potassium is secreted via the renal outer med- ullary $\mathrm{K}^{+}$channel (ROMK; Figure $1 \mathrm{~A}$ ). Intercalated cells are primarily responsible for urinary acidification, through $\mathrm{H}^{+}$ secretion by the vacuolar $\mathrm{H}^{+}$-ATPase or the $\mathrm{H}^{+} / \mathrm{K}^{+}$-ATPase found in $\alpha$-intercalated cells. When required, $\mathrm{HCO}_{3}{ }^{-}$secretion into the ultrafiltrate occurs via the $\mathrm{Cl}^{-} / \mathrm{HCO}_{3}$ exchanger pendrin (also known as SLC4A4) in $\beta$-intercalated cells $(1,2)$. This view presumes limited crosstalk between principal and intercalated cells, as a lack of gap junctions between these cell types limits their communication $(3,4)$.

As we learn more about properties of the distal nephron, distinctions between principal and intercalated cells are beginning to fade. Recent studies have shown 


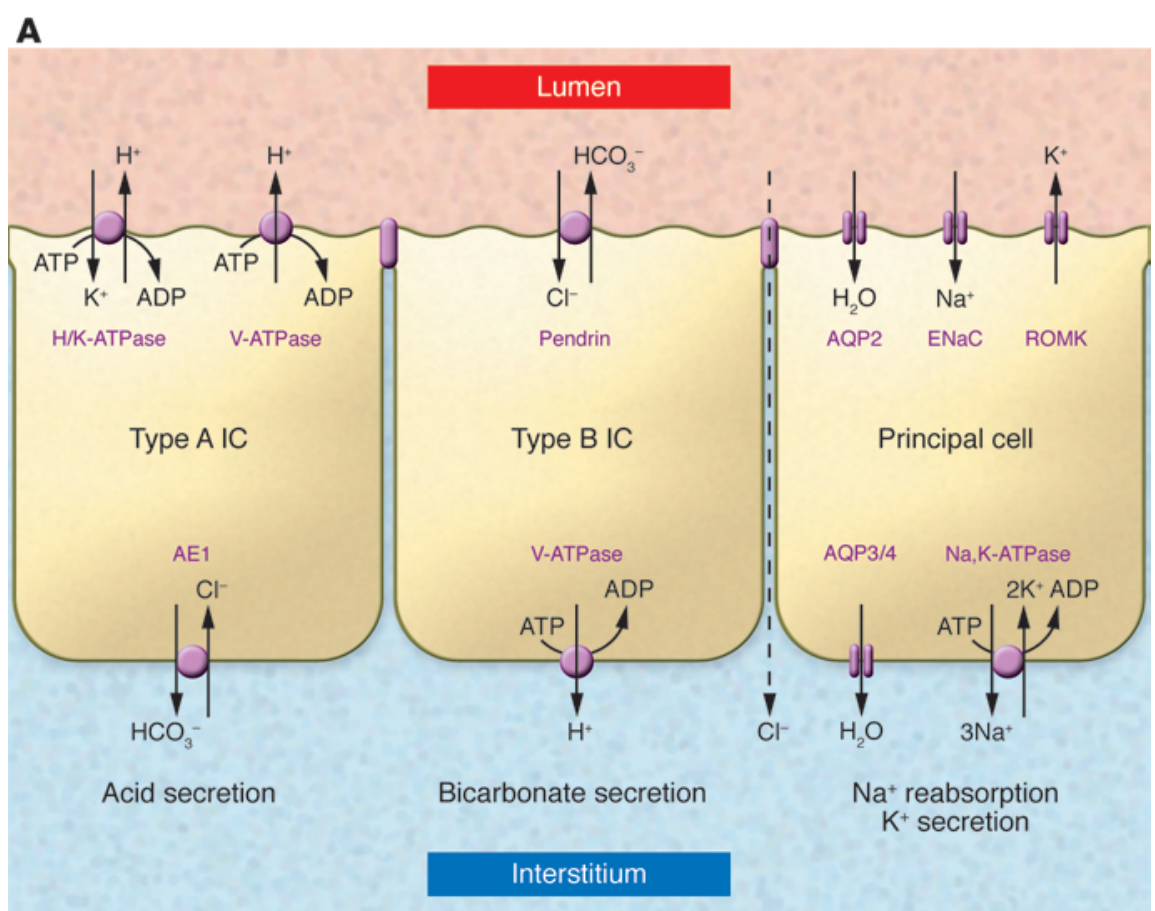

B

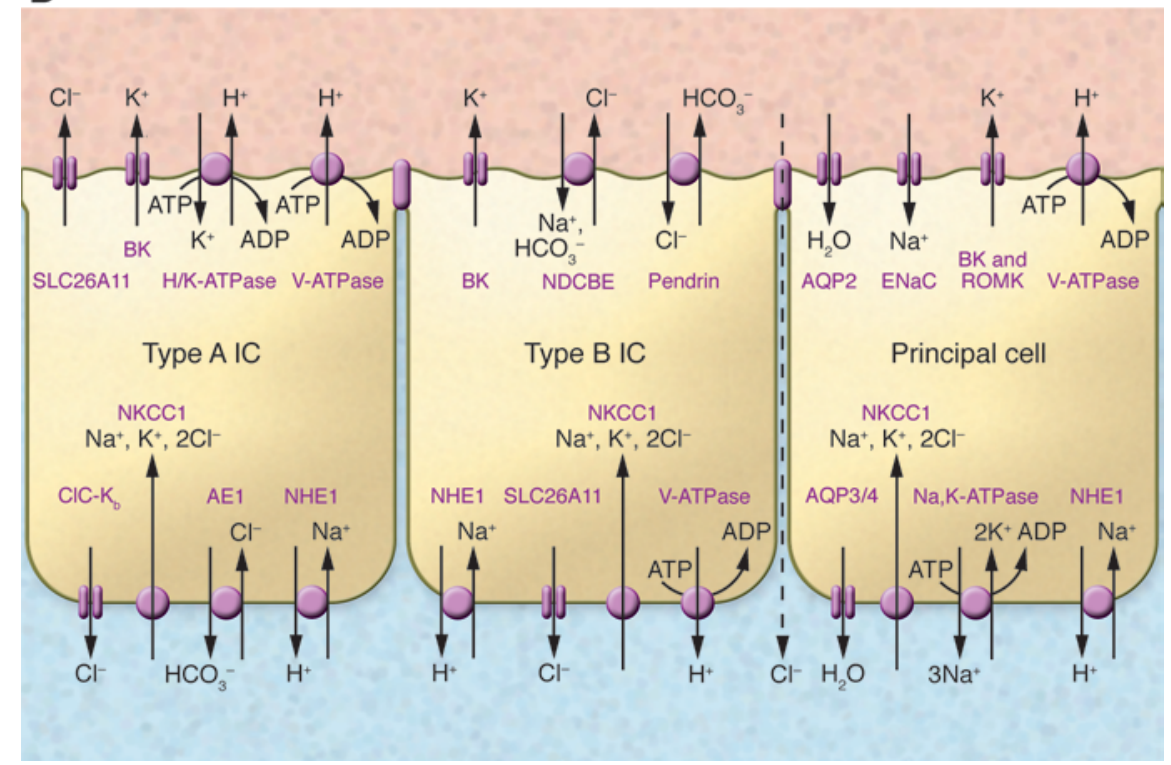

Figure 1

Evolving understanding of the distal nephron. (A) Traditional view, highlighting key transport proteins involved with acid/base, salt, and water balance in kidney collecting duct $\alpha$ (type A) and $\beta$ (type B) intercalated cells (ICs) and principal cells. (B) Updated view, based on studies performed in mice, rats, or rabbits. Although SLC26A11 is represented as a $\mathrm{Cl}^{-}$channel, there is evidence that it may also function as a $\mathrm{Cl}^{-} / \mathrm{HCO}_{3}{ }^{-}$exchanger. $\mathrm{AE} 1$, anion exchanger 1 ; $\mathrm{AQP}$, aquaporin; $\mathrm{ClC}-\mathrm{K}_{\mathrm{b}}, \mathrm{Cl}^{-}$channel, kidney-specific (type $\mathrm{B}$ ); $\mathrm{NDCBE}, \mathrm{Na}^{+}$-dependent $\mathrm{Cl}^{-} / \mathrm{HCO}_{3}{ }^{-}$exchanger; $\mathrm{NHE} 1, \mathrm{Na}^{+} / \mathrm{H}^{+}$exchanger 1 ; $\mathrm{NKCC} 1$, $\mathrm{Na}^{+} / \mathrm{K}^{+} / 2 \mathrm{Cl}^{-}$cotransporter 1 ; V-ATPase, vacuolar $\mathrm{H}^{+}$-ATPase.

that intercalated cells are capable of reabsorbing filtered $\mathrm{Na}^{+}$and $\mathrm{Cl}^{-}$via a luminal $\mathrm{Na}^{+}$-dependent $\mathrm{Cl}^{-} / \mathrm{HCO}_{3}{ }^{-}$exchanger, SLC4A8, which operates in parallel with pendrin (Figure 1B and refs. 2, 5). Reabsorption is not blocked by amiloride, a prototypic $\mathrm{ENaC}$ inhibitor, but is blocked by thiazide diuretics, which are also inhib- itors of NCC. The finding that mice overexpressing pendrin develop salt-sensitive hypertension suggests that this $\mathrm{NaCl}$ transport system has an important role in the reabsorption of filtered $\mathrm{NaCl}$ and regulation of extracellular fluid volume and blood pressure (6).

Evidence also suggests that intercalated cells, along with principal cells, participate in $\mathrm{K}^{+}$secretion that is activated by increased tubular flow rates. In this context, $\mathrm{K}^{+}$secretion is mediated by the luminal large-conductance $\mathrm{Ca}^{2+}$-activated $\mathrm{K}^{+}$ channel (referred to as the $\mathrm{BK}$ channel) and the basolateral $\mathrm{Na}^{+} / \mathrm{K}^{+} / 2 \mathrm{Cl}^{-}$cotransporter $(7,8)$. The findings that both individuals with Bartter syndrome as a result of ROMK loss-of-function mutations and mice lacking ROMK expression have robust renal $\mathrm{K}^{+}$secretion highlight the importance of this $\mathrm{BK}$ channel-mediated $\mathrm{K}^{+}$secretory pathway (9). Although neonates with loss of function ROMK mutations may exhibit early hyperkalemia (10), this likely reflects a delay in BK channel expression in the immediate postnatal period. Finally, identification of a luminal $\mathrm{H}^{+}$-ATPase in principal cells, although modest compared with intercalated cell $\mathrm{H}^{+}$-ATPase, raises the possibility that these cells may contribute to renal $\mathrm{H}^{+}$secretion (11).

\section{Working together}

Given the recent findings that principal and intercalated cells transport similar cations, it is likely that mechanisms have evolved to coordinate the transport of specific ions across these distinct cell types. For example, pendrin-dependent transport of $\mathrm{HCO}_{3}{ }^{-}$into the tubular lumen by intercalated cells enhances $\mathrm{ENaC}$ activity in principal cells (12). High tubular flow activates autocrine/paracrine prostaglandin $\mathrm{E}_{2}$ $\left(\mathrm{PGE}_{2}\right)$ release in the distal nephron, presumably via activation of cytosolic phospholipase 2 (cPLA2), which in turn regulates flow-stimulated $\mathrm{Na}^{+}$and $\mathrm{K}^{+}$transport in cortical collecting ducts (13). Gueutin and colleagues address the issue of functional crosstalk between intercalated and principal cells of the distal nephron in this issue of the JCI (14). Distal renal tubular acidosis is a clinical disorder associated with reduction or loss of distal nephron acid secretion. In humans, this disorder is accompanied by increased urinary $\mathrm{Ca}^{2+}$ losses, nephrocalcinosis, and chronic kidney disease. It is not surprising that humans with this disorder also exhibit enhanced renal $\mathrm{Na}^{+}$and $\mathrm{K}^{+}$losses, as this 
could simply reflect damaged cells within the distal nephron (15). The authors studied a mouse model of distal renal tubular acidosis in which the gene encoding the B1 subunit of the vacuolar $\mathrm{H}^{+}$-ATPase was disrupted (16). Previous characterization determined that these animals have a blunted response to increased acid load and do not have enhanced urinary $\mathrm{Ca}^{2+}$ losses or nephrocalcinosis.

Surprisingly, the authors found that these animals have an impaired ability to adapt to a low- $\mathrm{NaCl}$ diet. Normally, transition to a low- $\mathrm{NaCl}$ diet is accompanied by enhanced $\mathrm{Na}^{+}$reabsorption in the nephron and reduced urinary $\mathrm{Na}^{+}$excretion. Studies of cortical collecting ducts isolated from mice lacking the vacuolar $\mathrm{H}^{+}$-ATPase B1 subunit revealed that both $\mathrm{Na}^{+}$and $\mathrm{Cl}^{-}$ absorption were suppressed, as were transporters responsible for $\mathrm{Na}^{+}$and $\mathrm{Cl}^{-}$absorption (ENaC $\alpha$ and $\gamma$ subunits and pendrin) in this nephron segment. The impaired $\mathrm{Na}^{+}$ reabsorption was not due to reductions in the renin-angiotensin-aldosterone system, which is known to activate $\mathrm{Na}^{+}$transporters in the distal nephron. These findings raised the possibility that there are other factors responsible for blunting $\mathrm{NaCl}$ absorption in the distal nephron.

The authors found increased urinary excretion of $\mathrm{PGE}_{2}$ and ATP in mice lacking the vacuolar $\mathrm{H}^{+}$-ATPase B1 subunit. $\beta$-intercalated cells have a key role in the release of $\mathrm{PGE}_{2}$, as blocking vacuolar $\mathrm{H}^{+}$-ATPase in $\beta$-intercalated cells within isolated cortical collecting ducts was associated with enhanced $\mathrm{PGE}_{2}$ release. This prostanoid is a known inhibitor of $\mathrm{ENaC}$ (17). Extracellular ATP has a role in this process, as $\mathrm{PGE}_{2}$ release was dependent on ATP-dependent signaling via purinergic receptors. Extracellular ATP, released by connexin hemichannels and signaling through purinergic receptors, is also a known ENaC inhibitor that reduces channel open probability $(18,19)$.

In addition to the changes in renal $\mathrm{Na}^{+}$ handling, mice lacking expression of the vacuolar $\mathrm{H}^{+}$-ATPase $\mathrm{B} 1$ subunit had a urinary concentrating defect, reflecting reduced aquaporin 2 expression. When fed a low- $\mathrm{Na}^{+}$diet, these mice also exhibited enhanced renal $\mathrm{K}^{+}$loss, which appeared to be due to increased BK channel expression and increased urinary flow.

\section{A cooperative future}

In summary, the work presented by Gueutin and colleagues (14) introduces a new paradigm of crosstalk between principal and intercalated cells and provides further evidence that both cell types are important in maintaining $\mathrm{Na}^{+}$balance and thus blood pressure. This work also raises a number of questions that we hope will be addressed in future studies. While inhibition of basolateral vacuolar $\mathrm{H}^{+}$-ATPase in $\beta$-intercalated cells was necessary to see the crosstalk between intercalated and principal cells, we do not know whether this regulatory interaction is also seen when $\beta$-intercalated cell vacuolar $\mathrm{H}^{+}$-ATPase activity is reduced by endogenous regulatory factors, such as increased acid load associated with a "typical” Western diet. Do inhibitors of prostaglandin synthesis (e.g., indomethacin and other nonsteroidal antiinflammatory drugs) have a role in preventing urinary loss of $\mathrm{Na}^{+}$in individuals with congenital or acquired distal renal tubular acidosis, with the caveat that long-term use of the drugs may damage the kidney? What are the cellular mechanisms that lead to increased ATP release when vacuolar $\mathrm{H}^{+}$-ATPase in $\beta$-intercalated cells is inhibited? Are impairments in different components of this paracrine signaling pathway involved in the pathogenesis of salt-sensitive hypertension? The answers to these questions should provide useful information by which to understand the interaction between principal and intercalated cells, and also direct development of therapeutics for renal disease. On a final note, the authors' observations raise the possibility that other mechanisms of crosstalk exist between these cells to facilitate the coordinated regulation of transporters between intercalated and principal cells.

\section{Acknowledgments}

This work was supported by NIH grants DK038470 (to L.M. Satlin), DK051391 (to T.R. Kleyman), DK065161 (to T.R. Kleyman), and DK075048 (to K.R. Hallows).

Address correspondence to: Thomas R. Kleyman, Renal-Electrolyte Division, University of Pittsburgh, A919 Scaife Hall, 3550 Terrace Street, Pittsburgh, Pennsylvania 15261, USA. Phone: 412.647.3121; Fax: 412.648.9166; E-mail: kleyman@pitt.edu.
1. Madsen KM, Tisher CC. Structural-functional relationship along the distal nephron. Am JPhysiol. 1986; 250(6 pt 3):F1-F15.

2. Eladari D, Chambrey R, Peti-Peterdi J. A new look at electrolyte transport in the distal tubule. Annu Rev Physiol. 2012;74:325-349.

3. Biemesderfer D, Stanton B, Wade JB, Kashgarian M, Giebisch G. Ultrastructure of Amphiuma distal nephron: evidence for cellular heterogeneity. Am J Physiol. 1989;256(4 pt 1):C849-C857.

4. Liu W, Xu S, Woda C, Kim P, Weinbaum S, Satlin LM. Effect of flow and stretch on the $[\mathrm{Ca} 2+] \mathrm{i}$ response of principal and intercalated cells in cortical collecting duct. Am J Physiol Renal Physiol. 2003; 285(5):F998-F1012

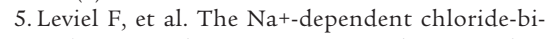
carbonate exchanger SLC4A8 mediates an electroneutral $\mathrm{Na}+$ reabsorption process in the renal cortical collecting ducts of mice. J Clin Invest. 2010; 120(5):1627-1635.

6. Jacques T, et al. Overexpression of pendrin in intercalated cells produces chloride-sensitive hypertension. J Am Soc Nephrol. 2013;24(7):1104-1113.

7. Satlin LM, Carattino MD, Liu W, Kleyman TR. Regulation of cation transport in the distal nephron by mechanical forces. Am J Physiol Renal Physiol. 2006; 291(5):F923-F931.

8. Liu W, et al. Role of NKCC in BK channel-mediated net $\mathrm{K}(+)$ secretion in the CCD. Am J Physiol Renal Physiol. 2011;301(5):F1088-F1097.

9. Bailey MA, et al. Maxi-K channels contribute to urinary potassium excretion in the ROMK-deficient mouse model of Type II Bartter's syndrome and in adaptation to a high-K diet. Kidney Int. 2006; 70(1):51-59.

10. Finer $\mathrm{G}$, et al. Transient neonatal hyperkalemia in the antenatal (ROMK defective) Bartter syndrome. $J$ Pediatr. 2003;142(3):318-323.

11. Liu W, Pastor-Soler NM, Schreck C, Zavilowitz B, Kleyman TR, Satlin LM. Luminal flow modulates $\mathrm{H}+$-ATPase activity in the cortical collecting duct (CCD). Am J Physiol Renal Physiol. 2012;302(1):F205-F215.

12. Pech V, et al. Pendrin modulates ENaC function by changing luminal HCO3. J Am Soc Nephrol. 2010; 21(11):1928-1941.

13. Flores D, Liu Y, Liu W, Satlin LM, Rohatgi R. Flow-induced prostaglandin E2 release regulates $\mathrm{Na}$ and $\mathrm{K}$ transport in the collecting duct. $\mathrm{Am} \mathrm{J}$ Physiol Renal Physiol. 2012;303(5):F632-F638.

14. Gueutin V, et al. Renal $\beta$-intercalated cells maintain body fluid and electrolyte balance. J Clin Invest. 2013; 123(10):4219-4231.

15. Sebastian A, McSherry E, Morris RC. Impaired renal conservation of sodium and chloride during sustained correction of systemic acidosis in patients with type 1, classic renal tubular acidosis. J Clin Invest. 1976;58(2):454-469.

16. Finberg KE, et al. The B1-subunit of the $\mathrm{H}(+)$ ATPase is required for maximal urinary acidification. Proc Natl Acad Sci U S A. 2005;102(38):13616-13621.

17. Stokes JB, Kokko JP. Inhibition of sodium transport by prostaglandin E2 across the isolated, perfused rabbit collecting tubule. J Clin Invest. 1977; 59(6):1099-1104.

18. Pochynyuk O, et al. Paracrine regulation of the epithelial $\mathrm{Na}+$ channel in the mammalian collecting duct by purinergic $\mathrm{P} 2 \mathrm{Y} 2$ receptor tone. J Biol Chem. 2008;283(52):36599-36607.

19. Mironova E, Peti-Peterdi J, Bugaj V, Stockand JD. Diminished paracrine regulation of the epithelial $\mathrm{Na}+$ channel by purinergic signaling in mice lacking connexin 30. J Biol Chem. 2011;286(2):1054-1060. 